\title{
AGRICULTURAL IMPACT ON ENVIRONMENTAL POLLUTION ON DISTRICT LEVEL
}

\author{
H. Harizanova-Bartos*, Z. Stoyanova, K. Todorova, R. Terziyska \\ Natural Resource Economics Department, Business Faculty, \\ University of National and World Economy, Sofia, Bulgaria
}

\begin{abstract}
With the introduction of new farming techniques and methods, the agrarian sector should be transformed into economically and environmentally friendly way. The Bulgarian districts are 28 and most of them are rural that contribute to the Bulgarian economy with GDP from agricultural products. The main aim of the study is to reveal the connection between the agrarian indicators GDP from agriculture and utilized agricultural area and their impact on the level of environmental pollution. The set up tasks are as follows: 1) Literature findings of the connection between agriculture and environmental pollution; 2) Methodology based on correlation, regression and Data Envelopment Analysis (DEA) of the impact on GDP from agriculture and environmental pollution; 3) Main findings, recommendations and conclusions. The results are part of scientific project DN 15/8 2017 "Sustainable multifunctional rural areas: reconsidering agricultural models and systems with increased demands and limited resources", funded by the Bulgarian science fund.
\end{abstract}

Key words: agriculture, environmental pollution, DEA, regression

\section{Literature review of the relationship between agriculture and pollution}

In many cases, agricultural activity could have negative impact on the environment and may create pressure on the natural resources and people's health. The links between agriculture and the environment are complex as agriculture is a major user of the land and water resources. Therefore the quantity and quality of these resources should be preserved so that the agricultural sector can remain viable.

Agriculture can create a risk to the environment by generating waste and pollution and by changing the landscapes and wildlife habitats, but also it can preserve and recycle the natural resources. Many of the risks to the environment are limited to the sector itself, but some of the negative effects also occur outside of agriculture. The impacts are often local and are concentrated in a particular region, although some of them are of national and

\footnotetext{
*Correspondence to: Hristina Harizanova-Bartos, Bulgaria, Sofia, Studentski grad, ul. Hristo Botev, +35928195529, e-mail: h.harizanova@gmail.com
}

international importance. Agricultural activity not only affects the environment but is also influenced by it. Plant growth can be affected by acid rain caused by increased $\mathrm{SO}_{2}$ and $\mathrm{NOx}$ concentrations or by increased ultraviolet radiation from the sun as well as by atmospheric pollution and climate change (1). According to some studies (2), as a major user of natural resources, agriculture has a significant environmental impact in OECD countries. Agriculture in OECD countries uses about $40 \%$ of the land and almost $45 \%$ of water resources, and in many countries it shapes the natural landscape. Unlike many other economic activities, agriculture has both negative and beneficial effect on the environment by changing the quality or quantity of soil, water, air, biodiversity and landscape.

The increasing demand for food resources along with policies to promote production, technological and economic change, often lead to uncertainty and risk to the environment as a result of the market intensification of agriculture and the realization of production on 
environmentally vulnerable lands. These negative consequences mainly include water and air pollution, but also loss of wildlife, habitats and landscape features. Soil degradation and depletion of water resources are serious problems due to agricultural activities (2).

The negative impact on the environment is the result of the intensification of agriculture, unsustainable use of resources and the use of pesticides, fertilizers and machinery. Water, soil, air and biodiversity are resources that are influenced by agricultural practices, and any environmental impacts resulting from agriculture affect them.

Some authors (3) consider that climate change is one of the main environmental risks and global environmental problems endangering the survival of the population. This is one of the risks with serious consequences for agriculture, natural ecosystems, water supply, health, soil and atmosphere - elements that ensure long-term sustainability of life on earth. The yield of crops is influenced by many factors associated with climate change, such as temperature, rainfall and other extreme meteorological phenomena. On the other hand, agriculture has an impact on climate change in different regions (4).

Agriculture can protect or pose a risk to the environment and natural resources. Other researchers (5) identify the main risks of agriculture on land and water resources and the importance of landscape for agricultural production, biodiversity conservation and ecosystem services. According to other authors (4), many agricultural activities can have an impact on the environment - land resources, water and air. Improper soil treatment, deforestation and forest fires are just some of the factors that cause soil degradation, reduction of soil fertility and pollution of water (6). These impacts on the environment vary according to the location of the farm, its specialization, specific farming and management practices, land management, and the timing of such practices. According to some authors (6) erosion remains a major degradation process. The type and mode of land use, the condition of the vegetation cover and the time during which the soil is protected by vegetation, determine the degree of risk and the soil losses caused by erosion. According to (6), agriculture also has an impact on water quality.
The main sources of nitrogen in surface water are household waste water from the population and rainwater from arable land. Higher concentrations of nitrogen are an indicator of the presence of one or other form of contamination. Nitrates are among the most commonly found pollutants in groundwater. At the same time, intensive irrigation and applied drainage practices also create environmental problems such as the reduction of water supplies and the loss of wetlands, which play an important role in regulating hydrological systems.

The reasons for the negative impact of agriculture on the environment are related to the usage of fertilizers, the use of plant protection products. Agriculture is a major source of methane and ammonia. Intensive livestock breeding is the cause of the release of methane and ammonia that pollute the atmosphere. Large amounts of manure released in liquid form are a major problem for modern livestock farms.

\section{Methodological framework}

The main aim of the study is to reveal the connection between GDP from agriculture, utilized agricultural area (UAA) and its impact on levels of environmental pollution. The set up tasks are as follows:

1) Literature findings of the connection between agriculture and environmental pollution. In this part are reviewed theories concerning agriculture as a polluter and how agricultural GDP is connected with emitted gasses in the atmosphere.

2) Methodology is based on correlation, regression and DEA of the impact of GDP from agriculture and environmental pollution. On the first level is shown the relationship between the researched indicators. For the purposes of this study, is evaluated the relationship strength (correlation analysis) and dependence (regression analysis) between three indicators - gross value added from agriculture, utilized agricultural area, arable land and carbon dioxide emission level in the atmosphere for the period 2011-2016.

3) The third part of the report highlights the main findings, recommendations and conclusions. The results are part of scientific $\begin{array}{lllll}\text { project DN } & 15 / 8 & 2017 & \text { Sustainable }\end{array}$ multifunctional rural areas: reconsidering agricultural models and systems with increased demands and limited resources funded by the Bulgarian science fund. 
On the first place, a correlation analysis is made which aims at establishing the strength of the relationship between two variables. Correlational research questions are those in which two or more variables are associated with each other (7). The answer to correlation scientific hypotheses is given by correlation and regression methods. The correlation does not suggest that a variable depends on one or more other variables. It analyzes and evaluates only the strength of the relationship, and whether or not there is an association between the two variables. Correlation is a measure for the strength of dependence between two variables, and correlation analysis is a statistical analysis that verify the hypothesis of a (non-random) connection between the variables. Since the correlation analysis does not investigate the relationship between two variables, regression analysis is used as the next step to establish the dependence. Unlike correlation, regression describes the dependent variable as a function of one or several independent variables.

After the correlation and regression analysis, it is applied an Input-oriented DEA that adopts a Constant Return to Scale (CRS). Data Envelopment Analysis (DEA) is widely used in the field of agrarian economics. Magdaleno and Garcia (8) analyze the differences in efficiency between producer organizations and investment firms in the Spanish agricultural sector. Using DEA, they assess the technical performance of agricultural companies in the northern part of Spain in 2004. Based on the results of the survey, they conclude that legal status is not critical to the organization's effectiveness and there is no significant difference in the performance of producer organizations compared to investment firms. In their study Barros and Santos (9) also used DEA to compare the performance of producer organizations and investment firms in the Portuguese wine industry. Their conclusion is that Portuguese wine producer organizations are more efficient than investment firms. In addition, the size of the company is an important factor in determining efficiency. Guzman et al (10) compare the effectiveness of Italian and Spanish producer organizations in the fruit and vegetable sector for the period 2001 to 2005 by applying DEA. The survey results show that Italian producer organizations have a higher ability to optimize input resources to maximize technical efficiency. Dios-Palomares et al (11) analyze the differences in technical efficiency in the olive oil industry in Andalusia over the period 20052006 , using DEA. Based on a sample of 88 companies, they believe that despite the level of efficiency, it is possible to reduce the use of raw materials and limit the impact of production on the environment. DEA is a nonparametric method for measuring efficiency of the decision making unit (DMU). It connects input to outputs as established effective units are on the efficiency frontier.

DEA is a model that permits a constant return to scale (CRS). It defines a single production / resource ratio as $100 \%$ effective and compares all units with it. It is possible for several units to get $100 \%$ if it is true for all of them that the input and output indicators are exactly in that ratio - the most optimal possible ratio for the efficiency of the production process. The units that have reached optimal efficiency define the boundary of production capabilities. For a DEA-Input-oriented model, the efficiency function of each unit under consideration takes values from 0 to $1(0 \%$ to $100 \%)$. This value indicates how much of the resources used would justify the output so that the production process is effective. In the input-oriented model, the levels of the product produced are considered to be constant and the levels of resources used can be changed (12). For coefficients of efficiency 1 , the district concerned can be defined as effectively using the production resource. The efficiency of each unit is expressed as the ratio of outputs and inputs used for its production. The most efficient units (can be more than one) receive an efficiency value of 1 or $100 \%$ and become the standard for the remaining units.

The main arguments for choosing the DEA method are:

- The analysis used can work with any homogeneous units. In general, the DEA method is used to compare the performance of businesses, NGOs, hospitals, schools and other.

- The analysis allows the use of resources and products in different units of measurement. Therefore, DEA is possible, without limitation by the type of unit of measure, which provides a wide variety of factors that can be investigated.

- A third advantage of the analysis is the application of a variety of DEA models. 


\section{RESULTS AND DISCUSSION}

Results from the correlation and regression analysis

Table 1 shows the correlation between the gross value added (GVA), the UAA, the arable land and the emission levels. Only those districts that show a level of statistical significance of 0.01 and 0.05 and a strength of 0.5-0.7 (strong correlation) and > 0.70 (very strong correlation) are selected. Regarding the first indicator of GVA from agriculture, it is noticed that in four of the districts (Bourgas, Sofia-region, Targovishte and Razgrad) the increase of the indicator increases the emission level, while for Varna and Lovech the connection is negative, meaning that with the
HARIZANOVA-BARTOS H., et al. increase in GVA emissions are actually decreasing.

The indicator for utilized agricultural area shows a positive and very strong correlation for four districts - Kardzhali, Pazardzhik, Lovech and Targovishte, with increasing UAA the emission level is also growing.

For the indicator of arable land, two of the districts show a negative correlation (Veliko Tarnovo and Sliven), with the increase of the arable area the emission level decreases. The other two districts - Ruse and Varna show a very strong correlation between the size of the arable land and the level of emissions in the atmosphere.

Table 1. Results from the correlation analysis between agrarian indicators and emission levels

\begin{tabular}{|c|c|c|c|c|c|}
\hline \multicolumn{2}{|c|}{ Gross added value } & \multicolumn{2}{|c|}{ Utilized agricultural area } & \multicolumn{2}{|l|}{ Arable land } \\
\hline Bourgas & $0.827 *$ & Kardzhali & $0.868^{*}$ & Ruse & $0.993 * *$ \\
\hline Varna & $-0.762 *$ & Pazardzhik & $0.829^{*}$ & Varna & $0.887^{*}$ \\
\hline Sofia Region & $0.671 *$ & Lovech & $0.814 *$ & Veliko Tarnovo & $-0.815^{*}$ \\
\hline Lovech & $-0.909 * *$ & Targovishte & $0.919 * *$ & Sliven & $-0.949^{* * *}$ \\
\hline Targovishte & $0.778^{*}$ & & & & \\
\hline Razgrad & $0.692 *$ & & & & \\
\hline
\end{tabular}

In order to establish the linear combination of the dependent variable "emission level in the atmosphere" and the three agrarian indicators gross value added, utilized agricultural area and arable land, a single linear regression analysis is further used. Table 2 shows those areas for which statistical significance is proven to predict the dependent variable from the independent variables. All the statistical significance requirements of the F-ratio used to verify the zero hypothesis $\mathrm{H}_{0}$ are fulfilled, that there is no linear dependence between the independent and dependent variables.

Since for the selected districts, this ratio is less than 0.05 , the result is statistically significant and the null hypothesis is rejected, therefore a linear dependence is present. Regression coefficients also show statistical significance. Because the statistically significant result does not give information about the strength of the result or its size, it is important to know the magnitude of the effect of the independent on the dependent variable. It is defined as the strength of dependence between independent and dependent variables or the importance of the difference between the levels of the independent and dependent variable. The value of the adjusted determinant coefficient (adjusted $\mathrm{R}^{2}$ ) indicates namely the magnitude of the effect. The percentage of changes in the level of emissions can be explained by the presented regression model with respect to the independent variables gross added value, utilized agricultural area and arable land.

Interpretation of the magnitude of the effect (in absolute terms), according to Cohen (13), is a value of the adjusted coefficient of determination (Adjusted $\mathrm{R}^{2}$ ) between 0.51-0.70 (greater or greater than the typical) and above 0.70 (much larger than typical). With regard to the gross value added indicator in Lovech and Targovishte, a dependence is found, with $79 \%$ and $52 \%$ of the changes in the level of emissions being explained by the presented regression model, i.e. the independent variable gross value added. For the utilized agricultural area in Lovech, Targovishte, Kardzhali and Pazardzhik, the value of the adjusted 
HARIZANOVA-BARTOS H., et al.

coefficient of determination (Adjusted $\mathrm{R}^{2}$ ) is $0.579,0.807,0.692$ and 0.688 , respectively, indicating that $57 \%, 80 \%, 69 \% 60 \%$ of changes in the emission level can be explained by the presented regression model, i.e. the independent UAA variable. In the districts Varna, Rousse, Veliko Tarnovo and Sliven there is a strong dependence between the arable land and the emission level. The value of the adjusted coefficient of determination is $0,734,0,983,0,580$ and 0,876 , respectively. Accordingly, $73 \%, 98 \%, 58 \%$ and $87 \%$ of the changes in the level of emissions can be explained by the presented regression model with an independent variable of arable land.

Table 2. Results of regression analysis

\begin{tabular}{|l|l|l|l|}
\hline Districts & $\begin{array}{l}\text { Adjusted R } \\
\text { GAV }\end{array}$ & $\begin{array}{l}\text { Adjusted R } \\
\text { UAA }\end{array}$ & $\begin{array}{l}\text { Adjusted R } \\
\text { Arable land }\end{array}$ \\
\hline Varna & & & $73 \%$ \\
\hline Lovech & $79 \%$ & $57 \%$ & \\
\hline Targovishte & $52 \%$ & $80 \%$ & \\
\hline Ruse & & & $98 \%$ \\
\hline Kardzhali & & $69 \%$ & \\
\hline Pazardzhik & & $60 \%$ & \\
\hline Veliko Tarnovo & & & $58 \%$ \\
\hline Sliven & & & $87 \%$ \\
\hline
\end{tabular}

Source: own calculations

\section{Results from the DEA model}

The decision-making units are the 28 districts in Bulgaria. The input is GVA from agriculture sector and output is emissions of carbon dioxide in the atmosphere. Table 3 presents the results of an Input-oriented DEA that allows a Constant Return to Scale (CRS). The model calculates the efficiency of each decision-making unit in terms of used input and output data (GVA from agriculture and carbon dioxide emissions into the atmosphere). According to the results Stara Zagora is the area which has coefficient of efficiency 1 and most effectively uses the resources compared to the other decision-making units. In 2016, Dobrich and Kardzhali have the lowest efficiency coefficient of the input and output data, respectively, of 0.001 units. The data show an increase in efficiency ratios in 2016 compared to 2013 in the following districts: Vratsa, Pleven, Razgrad, Pyce, Sliven, Smolyan, Targovishte and Shumen. The most significant change was observed in Pleven by 0.03 units (from 0.012 in 2013 to 0.041 in 2016). In all other 19 districts of the country the coefficient of efficiency in 2016 decrease, the most significant is the change in Kyustendil by 0.2 units.

Table 3. Results of DEA model

\begin{tabular}{|l|l|l|l|l|l|l|l|}
\hline NO & DMU & $\mathbf{2 0 1 3}$ & $\mathbf{2 0 1 6}$ & NO & DMU & $\mathbf{2 0 1 3}$ & $\mathbf{2 0 1 6}$ \\
\hline $\mathbf{1}$ & Stara Zagora & 1,000 & 1,000 & $\mathbf{1 5}$ & Gabrovo & 0,025 & 0,017 \\
\hline $\mathbf{2}$ & Sofia & 0,320 & 0,307 & $\mathbf{1 6}$ & $\begin{array}{l}\text { Veliko } \\
\text { Tarnovo }\end{array}$ & 0,038 & 0,010 \\
\hline $\mathbf{3}$ & Kyustendil & 0,497 & 0,298 & $\mathbf{1 7}$ & Pazardzhik & 0,009 & 0,009 \\
\hline $\mathbf{4}$ & Pernik & 0,218 & 0,225 & $\mathbf{1 8}$ & Lovech & 0,038 & 0,009 \\
\hline $\mathbf{5}$ & Varna & 0,272 & 0,188 & $\mathbf{1 9}$ & Shumen & 0,008 & 0,008 \\
\hline $\mathbf{6}$ & Sliven & 0,058 & 0,062 & $\mathbf{2 0}$ & Plovdiv & 0,018 & 0,007 \\
\hline $\mathbf{7}$ & Ruse & 0,057 & 0,058 & $\mathbf{2 1}$ & Yambol & 0,022 & 0,003 \\
\hline $\mathbf{8}$ & Targovishte & 0,033 & 0,048 & $\mathbf{2 2}$ & Smolyan & 0,002 & 0,003 \\
\hline $\mathbf{9}$ & Pleven & 0,012 & 0,041 & $\mathbf{2 3}$ & Vidin & 0,071 & 0,002 \\
\hline $\mathbf{1 0}$ & Haskovo & 0,054 & 0,035 & $\mathbf{2 4}$ & Blagoevgrad & 0,003 & 0,002 \\
\hline $\mathbf{1 1}$ & Vratsa & 0,023 & 0,029 & $\mathbf{2 5}$ & Montana & 0,002 & 0,002 \\
\hline $\mathbf{1 2}$ & Sofia (city) & 0,029 & 0,025 & $\mathbf{2 6}$ & Silistra & 0,003 & 0,002 \\
\hline $\mathbf{1 3}$ & Bourgas & 0,019 & 0,018 & $\mathbf{2 7}$ & Kardzali & 0,001 & 0,001 \\
\hline $\mathbf{1 4}$ & Razgrad & 0,015 & 0,017 & $\mathbf{2 8}$ & Dobrich & 0,001 & 0,001 \\
\hline
\end{tabular}

Source: own calculations 


\section{CONCLUSION}

From the studies and calculations made, the following conclusions can be drawn:

* There are differences in the regional level with regard to the indicators examined, both in relation to the relationship between agriculture and environmental pollution, as well as in strength and direction. The impact on the environment differs from the location of the farm, its specialization, specific farming and management practices, land management, and the timing of these practices.

* In the districts of Bourgas, Sofiaregion, Targovishte and Razgrad the increase of gross added value from agriculture increases the level of emissions.

* In the districts of Varna and Lovech the connection is negative, which means that with the increase of GVA from agriculture the emissions decrease.

* With respect to the utilized agricultural area there is a positive and very strong correlation for four districts - Kardzhali, Pazardzhik, Lovech and Targovishte, with increasing UAA the emission level also grows and a negative correlation in Veliko Tarnovo and Sliven where with the increase of the arable land area the emission level decreases. The other two districts - Ruse and Varna show a very strong correlation between the size of the arable land and the level of emissions in the atmosphere.

* Correlation analysis also reveals that there is dependence between the agrarian sector and pollution.

* With regard to GVA from agriculture and carbon dioxide emissions in the atmosphere and the presented DEA model, there are high levels of efficiency in almost all areas, as the observed changes in the two periods are negligible.

As a conclusion it could be noted that at this stage the Bulgarian agriculture in some districts does not contribute to the environmental pollution, but in other districts the technologies and methods of agricultural production reflect on higher levels of pollution.

\section{REFERENCES}

1. http://old.europe.bg/htmls/print_page.php?i $\mathrm{d}=5997 \&$ category $=8 \&$ print $=$ es $\&$ page $=8$

2. OECD, Agriculture and the Environment:Lessons Learned from a Decade of OECD Work. Paris: OECD Joint
HARIZANOVA-BARTOS H., et al.

Working Party on Agriculture and the Environment, 2004.

3. Emeka, D., Impact of climate change on livelihood sustainability in the lake chad region of Nigeria in Popoola. Proceedings of the 32nd Annual Conference of Forestry Association of Nigeria, pp.152-153, 2008.

4. Rohila, A.,Duhan, A., Maan, D.,Kumar, A., Kumar, K., Impact of agricultural practices on environment. Asian Journal of Microbiology. Biotechnology and Environmental Sciences, 19(2), 145-148, 2017.

5. MillenniumAssessment, The Millenium Ecosystem Assessment. Washington: Island Press, 2005.

6. EAE, Green book, 2004.

7. Ganeva, Z., Da preotkriem statistikata s IBM SPSS Statistics, Elektra EOOD, 2015 (in Bulgarian).

8. Magdaleno, M. I. A., \& García, J. G., Cooperatives versus corporates in the Spanish agricultural sector: non-parametric estimation of technical efficiency. In Anales de estudios económicos y empresariales (No. 19, pp. 61-90). Servicio de Publicaciones, 2009.

9. Barros, C. P., \& Santos, J. G., Comparing the productive efficiency of cooperatives and private enterprises: the Portuguese wine industry as a case study. Journal of rural cooperation, 35(2), 109, 2007.

10.Guzmán, I., Arcas, N., Ghelfi, R., \& Rivaroli, S., Technical efficiency in the fresh fruit and vegetable sector: a comparison study of Italian and Spanish firms. Fruits, 64(04), 243-252, 2009.

11.Dios-Palomares, R., Martínez-Paz, J. M., \& Prieto, A., Multi-output Technical Efficiency in the Olive Oil Industry and Its Relation to the Form of Business Organisation, In Efficiency Measures in the Agricultural Sector, Springer Netherlands, pp. 167-189, 2013.

12.Brainova, P., Sravnitelen analiz na vazmojni podhodi za izsledvane na srednata prodaljitelnost na predstoyashtiya jivot, Disertacionen trud za pridobivane na obrazovatelna I nauchna stepen "doctor", 2015 (in Bulgarian).

13.Cohen, J., Applied multiple regression/correlation analysis for the behavioral sciences, New York: Erlbaum, 1983. 